\title{
Controlling the passive oxide film formation on indium electrode in $\mathrm{Na}_{2} \mathrm{~B}_{4} \mathrm{O}_{7}$ solutions
}

\author{
Ahmed Diab ${ }^{1,2}$, Salah Abd El Wanees ${ }^{1,3}$ \\ ${ }^{1}$ Chemistry Department, Faculty of Science, Zagazig University, Zagazig, Egypt \\ ${ }^{2}$ Chemistry Department, Faculty of Preparatory Year, Jazan University, Jazan, KSA \\ ${ }^{3}$ Chemistry Department, Faculty of Science, Tabouk University, Tabouk, KSA
}

\section{Email address:}

ahmeddeiab@yahoo.com (A. Diab)

\section{To cite this article:}

Ahmed Diab, Salah Abd El Wanees. Controlling the Passive Oxide Film Formation on Indium Electrode in $\mathrm{Na}_{2} \mathrm{~B}_{4} \mathrm{O}_{7} \mathrm{Solutions}_{\text {. }}$ American Journal of Physical Chemistry. Vol. 3, No. 3, 2014, pp. 33-40. doi: 10.11648/j.ajpc.20140303.12

\begin{abstract}
The oxide film formation and growth on indium electrode in $\mathrm{Na}_{2} \mathrm{~B}_{4} \mathrm{O}_{7}$ solutions have been studied using polarization technique. The effects of concentration of $\mathrm{Na}_{2} \mathrm{~B}_{4} \mathrm{O}_{7}, \mathrm{pH}$ and temperature of electrolyte solution are investigated based on the formation of oxide film. It was found that lowering the concentrations of $\mathrm{Na}_{2} \mathrm{~B}_{4} \mathrm{O}_{7}$ solutions, $\mathrm{pH}$ or decreasing of temperature of the solution assist the formation of a passive oxide film on indium electrode. The corrosion current density, $\mathrm{i}_{\text {corr, }}$ increased with increasing the concentrations of $\mathrm{Na}_{2} \mathrm{~B}_{4} \mathrm{O}_{7}$ solutions, $\mathrm{pH}$ and the rising of solution temperature. The free activation energy of oxide film growth process is determined to be $15.7 \mathrm{~kJ} / \mathrm{mole}$. The above studies indicate that the oxide film growth process is diffusion-controlled. The effect of addition of $\mathrm{NaCl}, \mathrm{NaBr}$, and $\mathrm{NaI}$ with different amounts was also investigated. Higher concentrations of these salts lead to the dissolution of the passive oxide film due to the increasing of corrosion current density, $\mathrm{i}_{\text {corr, }}$ and the shift of corrosion potential, $\mathrm{E}_{\text {corr }}$, to more active potentials.
\end{abstract}

Keywords: Indium, $\mathrm{Na}_{2} \mathrm{~B}_{4} \mathrm{O}_{7}$, Oxide film, Anodic, Cathodic, Polarization, Tafel Slopes

\section{Introduction}

Indium was discovered in 1963 by F. Reich and T. Richer; it does not occur in the native state. Indium is most frequently associated with zinc, and is recovered commercially from zinc residues and smaller slags. These by-products constitute the main commercial sources of indium. For preparative details the reader is referred elsewhere [1].

Indium is a useful metal due to its applications to electronic and optoelectronic devices, solar cells, alkaline batteries, transparent conducting materials etc. Indium is mainly used as alloy compounds that are binary (Al-In, Bi$\mathrm{In}, \mathrm{Pb}-\mathrm{In}$ etc.), ternary (Al-Sb-In, $\mathrm{Cd}-\mathrm{Sn}-\mathrm{In}$ etc.), quaternary (Cd-Ge-Sn-In etc.) and quinary (Cd-Ge-Sn-ZnIn etc.) alloys $[2,3]$. Generally, the addition small quantity of indium has the effect of hardening, strengthening, and increasing the corrosion resistance of the metal. Some indium alloys such as InSb [4-7], InP [8, 9], InN [10, 11], InGaAs [12], InSe [13] are studied as optoelectronic materials, magneto resistive materials and anodic materials of lithium battery. Indium oxide is used as transparent conducting materials in the form of Sn-doped $\mathrm{In}_{2} \mathrm{O}_{3}$ (indium tin oxide, ITO) $[14,15]$. Because ITO films are optically transparent and electrically conductive in thin layers, glass fabricated ITO thin films are used for photovoltaic applications like liquid crystal displays. Currently there are many researchers who try to develop solar cells using indium contained semiconductors, such as InN [16,17], InGaN [18,19], $\mathrm{CuInS}(\mathrm{Se})_{2} / \mathrm{CuInGaS}(\mathrm{Se})_{2}$ [20-23].

Electrochemical processes at the indium surface are often affected by the presence of a stable surface oxide film. The formation, growth and properties of thin oxide films on indium in slightly alkaline solution have been studied recently [24-26] and it was found that the behavior of indium during anodic oxidation resembles in many aspects the kinetics of anodizing of valve metals. Furthermore, indium forms alloys with many other metals, usually having a marked hardening and strengthening effect if added in small quantities. For example, it is particularly effective in hardening and strengthening of lead, tin, copper, aluminium, zinc [27].

The formation and growth of a thin oxide film on polycrystalline indium in a borate buffer solution was 
examined [28]. Complex structural characterizations of the anodically formed indium oxide film have been studied using galvanostatic [28], cyclic voltammetry and impedance spectroscopy [29] techniques. It has been found that the behavior of indium during anodic oxidation resembles in many aspects the kinetics of anodization of valve metals (e.g. Ta, $\mathrm{Zr}$, Ti, Al, Sb, Bi). This conclusion has been deduced from the linearity between the current density and (i) the oxide formation rate ; (ii) the reciprocal capacity (the unitary formation rate); (iii) the potential drop across the oxide layer. The kinetics and chemical stability of potentiostatically formed indium oxide films were discussed by Saidman et al. [30] as a function of potential domain, time diffusing process, and hydroxide concentration. It has been concluded that the surface indium oxide film undergoes reductive decomposition to pure metallic indium in the solid phase, via the solid-state mechanism [30]. Thus, it is possible to generate an oxidefree indium surface in situ, by applying a sufficiently negative potential. This, together with the fact that indium has a large hydrogen evolution overpotential, is the basis for a possible application of indium as a cathode catalyst material [31]. Saidman et al. [30, 32] also discussed the kinetics and chemical stability of potentiostatically formed oxide films as a function of potential domain, time diffusing process, and hydroxide concentration. Munoz and Bessone [33] reported on the cathodic behavior of indium in the presence of chloride ions. The hydrogen evolution reaction and the effects of local alkalization, $\mathrm{Cl}^{-}$ ions concentration and the presence of surface oxide were analyzed. The data show the presence of a cathodic current density plateau (cd), this latter being attributed to a possible catalytic effect exerted by the oxide layer on the hydrogen evolution reaction. An increase of $\mathrm{Cl}^{-}$ions concentration generates a shift of the cd plateau towards lower cathodic cd values. The appearance of a rise in the anodic cd at a potential close to $-1.1 \mathrm{~V}$ was found to be dependent of the $\mathrm{Cl}^{-}$ions concentration and to be controlled by mass transfer.

The aim of the present work is to shed more light on the oxide film formation and growth on an indium electrode in sodium borate solutions. The effect of the some factors, e.g., solution concentration $\left(1 \times 10^{-4}-1 \times 10^{-1} \mathrm{M}\right)$, and $\mathrm{pH}$ (9.13-11.49), as well as, temperature changes $\left(25-55^{\circ} \mathrm{C}\right)$ on the initial rate of oxide film growth are examined. The effect of addition of some aggressive salts such as, $\mathrm{NaCl}$, $\mathrm{NaBr}$ and $\mathrm{NaI}$ on the stability of the oxide film formed is also examined.

\section{Experimental}

The working electrode was made from $99.99 \%$ pure indium rod $0.35 \mathrm{~cm}$ thick (Aldrich). The electrode was fixed to borosilicate glass tubes with epoxy resin so that the total exposed surface area was $0.384 \mathrm{~cm}^{2}$. Electrical contacts were achieved through thick copper wires soldered to the ends of the indium rod not exposed to the solution. Before being used, the indium electrode was abraded into uniform surfaces by a grinding machine (model Jean Wirtz TG 200, Germany) using successive 0-, 00- and 000-grades emery papers, rinsed with acetone and finally washed with triply distilled water before immersing in the test solution.

The polarization measurements were conducted using the galvanostatic technique. Before starting the polarization, the electrode was immersed in the electrolyte until the steady-state corrosion potential was reached. Then polarization of the electrode was started anodically or cathodically using low current density, followed by higher ones. The potential was recorded on a digital multimeter. For each current density used, the steady-state potential of the metal was considered when its value did not change by more than $1 \mathrm{mV}$ in 10 minutes. Each run was carried out in a fresh naturally aerated $\mathrm{Na}_{2} \mathrm{~B}_{4} \mathrm{O}_{7}$ solution and with a newly polished electrode. The cell has a double wall jacket through which water, at the adjusted temperature, was circulated. Measurements were carried out at a constant temperature $25 \pm 0.1^{\circ} \mathrm{C}$, except those related to the effect of temperature. The cell temperature was controlled using an ultra thermostat type polyscience (USA). The main joint of the cell contains openings for, the indium electrode, the reference electrode (SCE) and one opening for the platinum counter electrode. This latter was fitted into a compartment separated from the main bulk of the electrolyte by means of $\mathrm{G}_{4}$ sintered glass disc to affect separation of the anode and the cathode reactions products. No trails were made to measure the oxygen content of the solution.

Electrolytic solutions were prepared from analytical grade reagents and triply-distilled water. Solutions of $\mathrm{Na}_{2} \mathrm{~B}_{4} \mathrm{O}_{7}$ with different concentrations were prepared by dissolving the corresponding quantitative weights of solid $\mathrm{Na}_{2} \mathrm{~B}_{4} \mathrm{O}_{7}$ in the appropriate volumes of distilled water. The $\mathrm{pH}$ of the solution was adjusted by dropwise addition of $\mathrm{NaOH}$ solution using an Orion Research Expandable Ion Analyzer EA 920. The effect of temperature was carried out as mentioned above. The effect of adding variable concentrations of $\mathrm{NaCl}, \mathrm{NaBr}$ and $\mathrm{NaI}$ ranged from $1 \times 10^{-4} \mathrm{M}$ to $1 \times 10^{-2} \mathrm{M}$ was tested in the presence of definite concentration of $\mathrm{Na}_{2} \mathrm{~B}_{4} \mathrm{O}_{7}$ as $1 \times 10^{-3} \mathrm{M}$.

\section{Results and Discussion}

\subsection{Effect of $\mathrm{Na}_{2} \mathrm{~B}_{4} \mathrm{O}_{7}$ Concentration}

Indium metal oxidizes to produce a film of $\mathrm{In}_{2} \mathrm{O}_{3}$ or $\mathrm{In}(\mathrm{OH})_{3}$ in an alkaline solution. Omanovic and MetikosHokovic [34] studied the mechanism and kinetics of nucleation and growth of indium oxide film on a bare metallic indium electrode in a borate solution of $\mathrm{pH} 10.0$ using cyclic voltammetry and chronoamperometry techniques. The cyclic voltammograms of indium electrode showed very well defined single anodic and cathodic current peaks, the potential of which depends on the scan rate employed. These anodic and cathodic peaks were related to the reversible formation and reduction of an Indium oxide layer, respectively, according to the following: 


$$
2 \mathrm{In}^{0}+6 \mathrm{OH}^{-} \leftrightarrow \mathrm{In}_{2} \mathrm{O}_{3}+3 \mathrm{H}_{2} \mathrm{O}+6 \mathrm{e}
$$

The experimental results showed that the oxide formation and reduction process was highly reversible and the initial stage of nucleation of the oxide film included a three dimensional progressive nucleation process, combined with a diffusion-controlled growth of the stable indium oxide crystals. The thermodynamic data obtained from this study indicated a strong tendency of indium to form an indium oxide film on its surface in an aqueous solution, which has been concluded on the basis of a very low nucleation over potential and low Gibbs free energy of nuclei formation. The rate determining step in the nucleation and growth process was the surface diffusion of electroactiv species.

Table 1. Variation of the kinetic parameters, $E_{\text {corr. }}, i_{c o r r}, \beta_{a}, \beta_{c}, R_{p}$ and $\delta_{O}$ for indium electrode with the concentration of $\mathrm{Na}_{2} \mathrm{~B}_{4} \mathrm{O}_{7}, \mathrm{pH}$ and temperature as calculated from Figs.1, 2 and 4.

\begin{tabular}{|c|c|c|c|c|c|c|c|}
\hline Property & & $-E_{\text {corr., }}, m V$ & $\mathbf{i}_{\text {corr. }}, \mathrm{mAcm}^{-2}$ & $\beta_{a}, \mathrm{mV}$ decade $^{-1}$ & $\beta_{c}, \mathrm{mV}_{\text {decade }}{ }^{-1}$ & $\mathbf{R}_{\mathrm{p}}, \mathbf{\Omega}$ & $\delta_{0}, \mathbf{n m}$ \\
\hline \multirow{6}{*}{ Concentration, $\mathrm{M}$} & $1 \times 10^{-4}$ & 342 & 0.0354 & 558.37 & -493.36 & 3.210 & 1.365 \\
\hline & $1 \times 10^{-3}$ & 418 & 0.0446 & 524.53 & -478.47 & 2.433 & 1.283 \\
\hline & $5 \times 10^{-3}$ & 470 & 0.0708 & 381.54 & -463.58 & 1.282 & 0.933 \\
\hline & $1 \times 10^{-2}$ & 494 & 0.0832 & 232.64 & -428.83 & 0.785 & 0.569 \\
\hline & $5 \times 10^{-2}$ & 544 & 0.1120 & 233.53 & -264.72 & 0.479 & 0.571 \\
\hline & 0.1 & 568 & 0.1318 & 196.31 & -249.83 & 0.363 & 0.480 \\
\hline \multirow{5}{*}{$\mathrm{pH}$} & 9.13 & 418 & 0.0446 & 524.53 & -478.47 & 2.433 & 1.283 \\
\hline & 9.83 & 433 & 0.0501 & 381.54 & -433.65 & 1.756 & 0.933 \\
\hline & 10.51 & 446 & 0.0562 & 242.75 & -411.38 & 1.177 & 0.593 \\
\hline & 11.29 & 463 & 0.0708 & 235.31 & -403.94 & 0.910 & 0.575 \\
\hline & 11.49 & 490 & 0.0794 & 225.84 & -396.49 & 0.785 & 0.552 \\
\hline \multirow{4}{*}{ Temperature, $\mathrm{K}$} & 298 & 418 & 0.0446 & 524.53 & -478.47 & 2.433 & 1.283 \\
\hline & 308 & 438 & 0.0537 & 518.09 & -499.54 & 2.056 & 1.267 \\
\hline & 318 & 458 & 0.0660 & 488.79 & -543.27 & 1.691 & 1.205 \\
\hline & 328 & 478 & 0.0794 & 462.41 & -601.93 & 1.429 & 1.131 \\
\hline
\end{tabular}

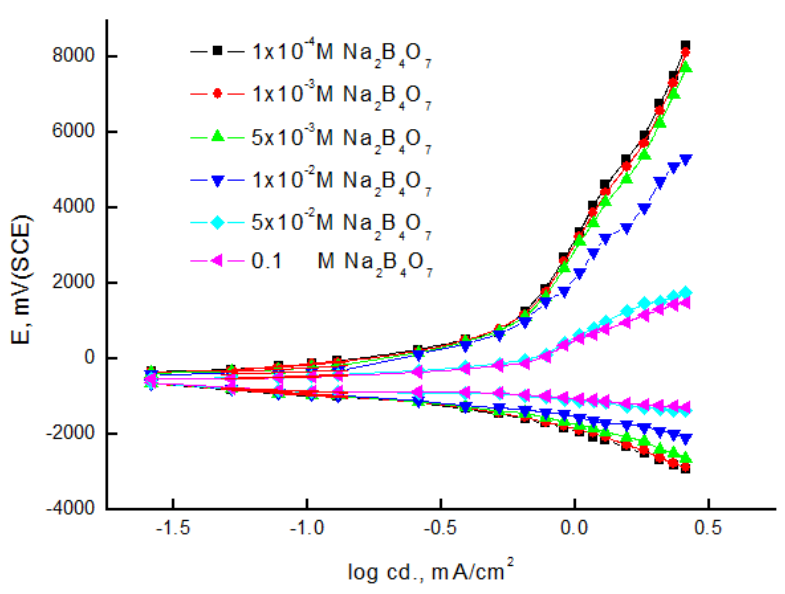

Fig. 1. Anodic and cathodic polarization curves of the indium electrode in different solutions of $\mathrm{Na}_{2} \mathrm{~B}_{4} \mathrm{O}_{7}$ of increasing concentrations at $25^{\circ} \mathrm{C}$.

Fig. 1 shows the galvanostatic anodic and cathodic polarization curves for the indium electrode in naturally aerated solutions of $\mathrm{Na}_{2} \mathrm{~B}_{4} \mathrm{O}_{7}$ of increasing concentrations at $25^{\circ} \mathrm{C}$. The results show that, as the concentration of $\mathrm{Na}_{2} \mathrm{~B}_{4} \mathrm{O}_{7}$ increases, the anodic polarization curves shift to more active direction and the cathodic polarization curves shift to more noble direction. The values of the anodic and cathodic Tafel slopes, $\beta_{\mathrm{a}}$ and $\beta_{\mathrm{c}}$, as well as, the corrosion potential, $\mathrm{E}_{\text {corr }}$, corrosion current density, $\mathrm{i}_{\text {corr, }}$ and polarization resistance, $R_{p}$, are shown in Table 1 . The corrosion current, $i_{\text {corr }}$, was obtained by extrapolation of the Tafel lines to the equilibrium potential. The polarization resistance, $R_{p}$, can be calculated from the Stern-Geary relationship as [35]:

$$
\mathrm{i}_{\text {corr }}=\left[\beta_{\mathrm{a}} \beta_{\mathrm{c}} / 2.303\left(\beta_{\mathrm{a}}+\beta_{\mathrm{c}}\right) \mathrm{R}_{\mathrm{p}}\right]=\mathrm{B} / \mathrm{R}_{\mathrm{p}}
$$

Inspection of Fig. 1 and the data of Table 1, reveals that the Tafel slopes, $\beta_{\mathrm{a}}$ and $\beta_{\mathrm{c}}$ are affected by increasing the $\mathrm{Na}_{2} \mathrm{~B}_{4} \mathrm{O}_{7}$ concentration. At the same time, the corrosion current density, $\mathrm{i}_{\text {corr }}$, increases markedly while the corrosion potential becomes more active. This behavior could be explained on the basis of the partial dissolution of the passivating oxide as the concentration of $\mathrm{Na}_{2} \mathrm{~B}_{4} \mathrm{O}_{7}$ solution increased.

The initial indium oxide film formed in $0.1 \mathrm{M} \mathrm{Na}$-borate buffer solution, $\mathrm{pH} 10$ is entirely under the diffusion control and formation of a monolayer film had a thickness of 0.43 $\mathrm{nm}$ [34]. This value is in accordance with the crystal structure parameters of $\operatorname{In}_{2} \mathrm{O}_{3}$ [36]. The values of peroxide thickness, $\delta_{0}$, can be estimated from the $\mathrm{E}$ versus $\log \mathrm{i}$ relations i.e. the usual Tafel relations of the electrode, this can be represented by the following equation [37]:

$$
(\mathrm{dE} / \mathrm{d} \ln \mathrm{i})=\left(\delta_{\mathrm{o}} / \mathrm{B}\right)+\text { constant }
$$

where $\mathrm{B}$ is the electrolytic parameter and the value of constant equal $(v \mathrm{Q} / \sigma \mathrm{B}) . \sigma=2, \sigma \mathrm{B}=4.892 \times 10^{-6} \mathrm{~cm} \mathrm{~V}^{-1}, v=$ $6.679 \times 10^{-5} \mathrm{~cm}^{-3} \mathrm{C}^{-1}$ for $\operatorname{In}_{2} \mathrm{O}_{3}$ and $\mathrm{Q}$ is the charge. At lower current densities, we can neglect the value of the constant and equation (3) can be represented by the simple form:

$$
(\mathrm{dE} / \mathrm{d} \ln \mathrm{i})=\left(\delta_{\mathrm{o}} / \mathrm{B}\right)
$$

considering the values of the anodic Tafel lines for the concentration from $1 \times 10^{-4} \mathrm{M}$ up to $0.1 \mathrm{M}$, the values of the $\delta_{\mathrm{o}}$ were ranged from $1.44 \mathrm{~nm}$ to $0.44 \mathrm{~nm}$, see Table 1 . From these values of $\delta_{0}$, we can conclude that lower concentrations of Na-borate assist the formation of $\operatorname{In}_{2} \mathrm{O}_{3}$ 


\subsection{Effect of $P H$}

The curves of Fig. 2 represent the anodic and cathodic polarization $\mathrm{E} / \log \mathrm{i}$ curves of the indium electrode in naturally aerated $1 \times 10^{-3} \mathrm{M} \mathrm{Na}_{2} \mathrm{~B}_{4} \mathrm{O}_{7}$ solutions of $\mathrm{pH}$ values ranged from 9.13 to 11.49 at $25^{\circ} \mathrm{C}$. It is noted that on increasing the $\mathrm{pH}$ of solution, the anodic polarization curves shift into the active direction and the cathodic polarization curves into the noble direction. The kinetic parameters $\beta_{\mathrm{a}}, \beta_{\mathrm{c}}, \mathrm{i}_{\text {corr }}, \mathrm{R}_{\mathrm{p}}$ and $\mathrm{E}_{\text {corr }}$ are calculated and shown in Table 1.

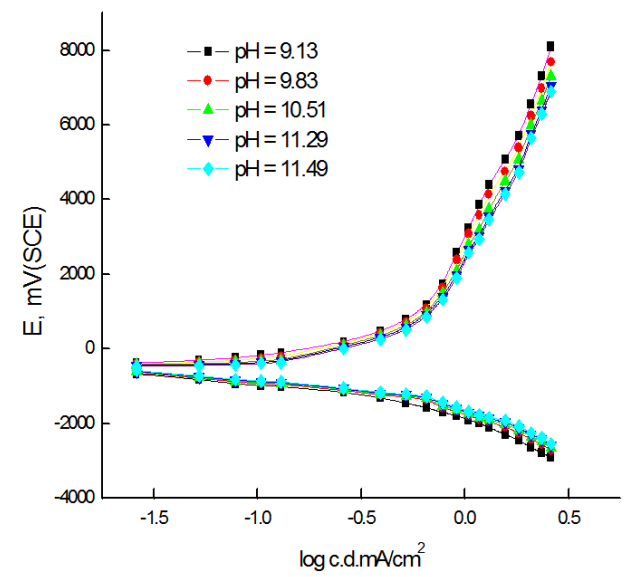

Fig. 2. Anodic and cathodic polarization curves of the indium electrode in $1 \times 10^{-3} \mathrm{M} \mathrm{Na}_{2} \mathrm{~B}_{4} \mathrm{O}_{7}$ solution at different $\mathrm{pH}$ values at $25^{\circ} \mathrm{C}$.

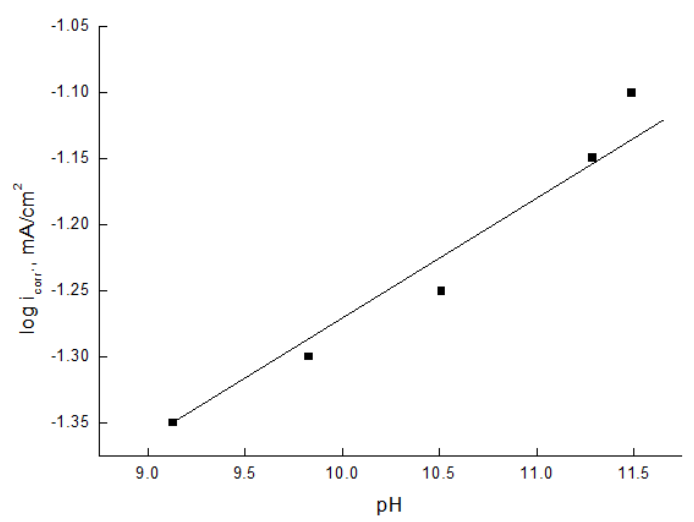

Fig. 3. Variation of the corrosion current density, $i_{\text {corr, }}$, of the indium electrode with the $\mathrm{pH}$ of the solution in $1 \times 10^{-3} \mathrm{MNa}_{2} \mathrm{~B}_{4} \mathrm{O}_{7}$ at $25^{\circ} \mathrm{C}$.

The relationship between the corrosion current densities, $\mathrm{i}_{\text {corr }}$, and the $\mathrm{pH}$ values is shown in Fig. 3 It is clear that on increasing the $\mathrm{pH}$ values, $\mathrm{i}_{\text {corr }}$, increases according to the relation:

$$
\log \mathrm{i}_{\text {corr }}=\mathrm{a}+\mathrm{bpH}
$$

where $\mathrm{a}$ and $\mathrm{b}$ are constants. From the data reported in Table 1 and the curves of Figs. 2, 3 it is clear that on increasing the $\mathrm{pH}$ of solution, the following conclusions could be drawn:

1) $\beta_{c}$ remains or less unchanged while $\beta_{a}$ decreases.

2) $i_{\text {corr }}$ is markedly increased while $E_{\text {corr }}$ becomes more active.

3) $R_{p}$ and $\delta_{O}$ decreases markedly.
These behaviors could be attributed to an increased rate of passive film destruction on increasing the $\mathrm{pH}$ of solution.

With increasing the $\mathrm{pH}$ of the solutions, the following reaction can be written by this way [38]:

$$
\mathrm{In}+\mathrm{OH}^{-} \rightarrow \operatorname{In}(\mathrm{OH})_{\mathrm{ad}}+\mathrm{e}^{-}
$$

an increasing adsorption of $\mathrm{OH}^{-}$species, preceding lattice dissolution, was related to a porous structure of the surface layer on the electrolyte side where the overall surface process could be summarized by the following reaction [39]:

$$
\mathrm{In}(\mathrm{OH})_{\mathrm{ad}}+2 \mathrm{OH}^{-} \rightarrow \operatorname{In}(\mathrm{OH})_{3}+2 \mathrm{e}^{-}
$$

the Eq. (7) can be also considered as the sum of consecutive one electron step processes [40]. The kinetics of the Eqs.(6) and (7) are determined by their corresponding reaction order with respect to $\mathrm{OH}^{-}$ion at the reaction site, as this should depend on the rate of transport of $\mathrm{OH}^{-}$ions from the bulk of the solution. Thus, the participation of soluble In(III) species just from the initial electrooxidation process, through Eq.(6) and the reaction: $\mathrm{In}(\mathrm{OH})_{\mathrm{ad}}+3 \mathrm{OH}^{-} \rightarrow \mathrm{In}(\mathrm{OH})_{4}{ }^{-}+2 \mathrm{e}^{-}$is possible at increasing $\mathrm{OH}^{-}$ion concentration. Simultaneously, an $\mathrm{In}(\mathrm{OH})_{3}$ film can be formed through Eq. (7), or by a dissolutionprecipitation mechanism coming from the equation $\operatorname{In}(\mathrm{OH})_{3}$ $+\mathrm{OH}^{-} \rightarrow \mathrm{In}(\mathrm{OH})_{4}^{-}$favored by the changing $\mathrm{pH}$ at the interface [41].

\subsection{Effect of Temperature}

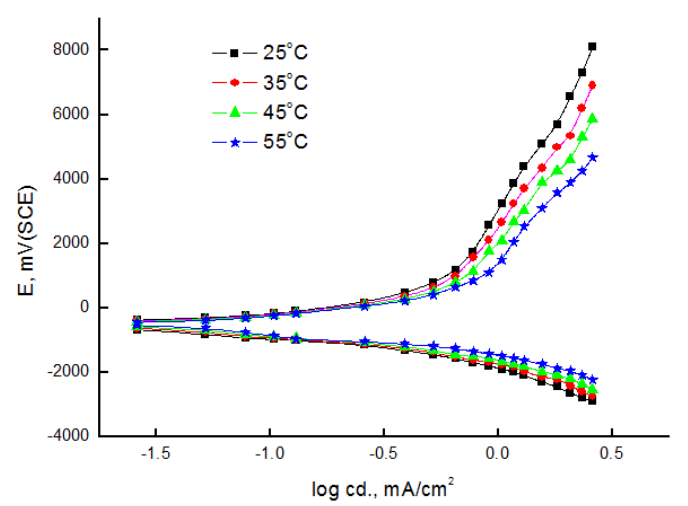

Fig. 4. Polarization curves of the indium electrode in $1 \times 10^{-3} \mathrm{M} \mathrm{Na}_{2} \mathrm{~B}_{4} \mathrm{O}_{7}$ solution at different temperatures.

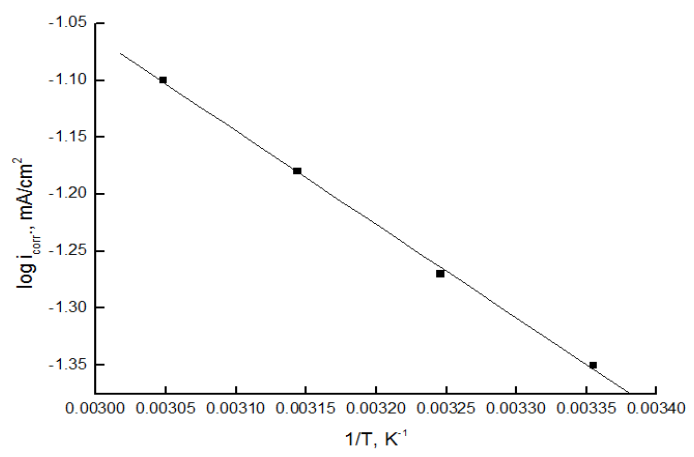

Fig 5. Arrhenius plot of Log $i_{\text {corr, }}$ versus $1 / T$ for the indium electrode in $1 \times 10^{-3} \mathrm{MNa}_{2} \mathrm{~B}_{4} \mathrm{O}_{7}$ solution. 
The influence of raising the temperature from $\left(25^{\circ} \mathrm{C}-\right.$ $55^{\circ} \mathrm{C}$ ), on the galvanostatic anodic and cathodic polarization curves of the indium electrode in naturally aerated $1 \times 10^{-3} \mathrm{M} \mathrm{Na}_{2} \mathrm{~B}_{4} \mathrm{O}_{7}$ solution is shown in Fig.4. It is clear from this figure that raising the temperature causes the shift of the anodic polarization curves into the cathodic direction and the cathodic polarization curves into the anodic direction. In Table 1 , the values of the kinetic parameters $\beta_{\mathrm{a}}, \beta_{\mathrm{c}}, \mathrm{i}_{\text {corr, }} \mathrm{E}_{\mathrm{corr}}$ and $\mathrm{R}_{\mathrm{p}}$ are shown. From the values of $i_{\text {corr }}$ and $E_{\text {corr }}$, raising the temperature enhances the dissolution of the passive film on the indium surface. Fig. 5 shows the Arrhenius plot of $\log \mathrm{i}_{\text {corr }}$ versus $1 / \mathrm{T}$, from which the free activation energy of oxide film formation, $\mathrm{E}_{\mathrm{a}}{ }_{\mathrm{a}}$, is determined:

$$
\log \mathrm{i}_{\text {corr }}=-\mathrm{E}_{\mathrm{a}}^{*} / 2.303 \mathrm{RT}+\text { constant }
$$

The value of $\mathrm{E}_{\mathrm{a}}^{*}$ for the indium electrode in $1 \times 10^{-3} \mathrm{M}$ solution of $\mathrm{Na}_{2} \mathrm{~B}_{4} \mathrm{O}_{7}$ is found to be $15.708 \mathrm{kJmol}^{-1}$, indicating that the process of oxide film growth is under diffusion control.

\subsection{Effect of Addition of Halo ions}

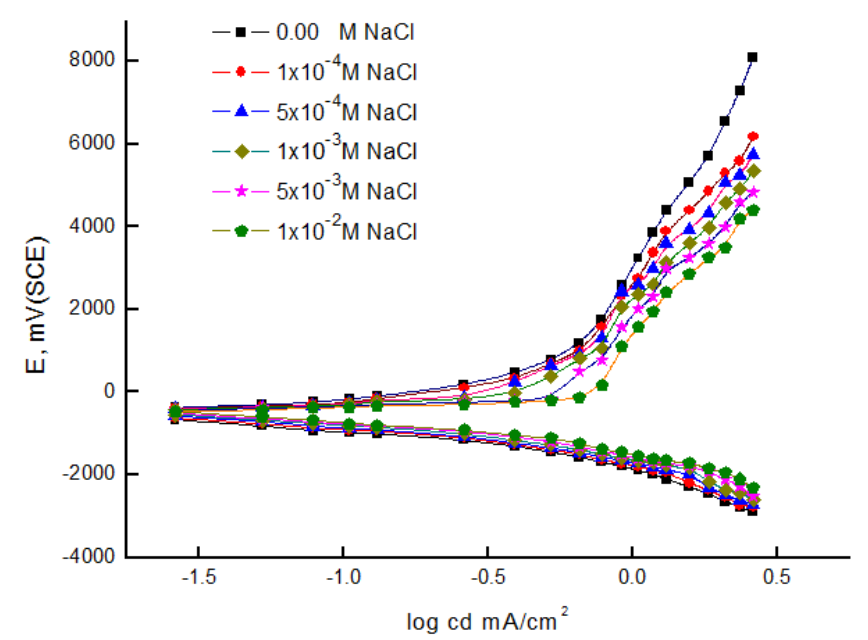

Fig. 6. Polarization curves of the indium electrode in $1 \times 10^{-3} \mathrm{M} \mathrm{Na}_{2} \mathrm{~B}_{4} \mathrm{O}_{7}$ solution devoid of-and containing different concentrations of $\mathrm{NaCl}$ at $25^{\circ} \mathrm{C}$.

The effect of addition increasing concentrations of $\mathrm{NaCl}$, $\mathrm{NaBr}$ and $\mathrm{NaI}$ on the galvanostatic anodic and cathodic polarization curves of the indium electrode in naturally aerated $1 \times 10^{-3} \mathrm{M} \mathrm{Na}_{2} \mathrm{~B}_{4} \mathrm{O}_{7}$ solution is shown in Figs. 6-8, respectively. From the curves of Figs. 6-8, it is clear that the addition of increasing concentrations of $\mathrm{NaCl}, \mathrm{NaBr}$ and $\mathrm{NaI}$ shifts the anodic polarization curves into the more active direction and the cathodic polarization curves into the noble direction. The corresponding anodic and cathodic Tafel slopes, as well as, the other kinetic parameters, $\mathrm{i}_{\text {corr, }}$ $\mathrm{E}_{\text {corr }}$ and $\mathrm{R}_{\mathrm{p}}$ are given in Table (2). Inspection of the data of Table (2) reveals that the presence of $\mathrm{NaCl}, \mathrm{NaBr}$ and $\mathrm{NaI}$ has a marked effect on the anodic Tafel slopes, $\beta_{\mathrm{a}}$, while the cathodic Tafel slopes, $\beta_{c}$, remains more/or less unchanged, indicating the enhancing effect of the aggressive anions on the anodic reaction. Thus, the presence of, the aggressive anions increases the ease of anodic reaction [42]. The influence of $\mathrm{Cl}^{-}, \mathrm{Br}^{-}$and $\mathrm{I}^{-}$ions on the passivity breakdown of indium can be interpreted as on the basis of a balance between two processes competing on the metal surface; stabilization of the passive film by $\mathrm{OH}^{-}$adsorption and disruption of the film by adsorption of $\mathrm{Cl}^{-}, \mathrm{Br}^{-}$and $\mathrm{I}^{-}$ions on the metal surface [43]. Halide is known to form a soluble complex with an indium ion. The formation mechanism and stability constants of indium halogenide complexes were investigated [44-46]. In the presence of halide ions $\left(\mathrm{Cl}^{-}, \mathrm{Br}^{-}, \mathrm{I}^{-}\right), \mathrm{In}^{3+}$ exists in the form of complexes of $\operatorname{InX}^{2+}, \operatorname{InX}_{2}^{+}, \operatorname{InX}_{3}$ and $\mathrm{InX}_{4}^{-}$. Munoz and Bessone [33] investigated that, lower oxide stability in the presence of a greater $\mathrm{Cl}^{-}$and generate increasing amounts of soluble species.

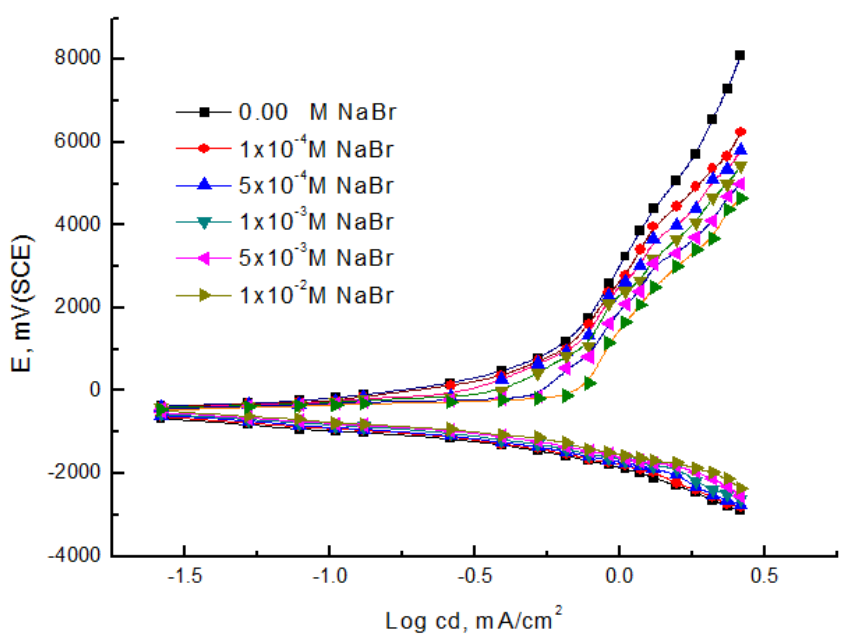

Fig. 7. Polarization curves of the indium electrode in $1 \times 10^{-3} \mathrm{M} \mathrm{Na}_{2} \mathrm{~B}_{4} \mathrm{O}_{7}$ solution devoid of-and containing different concentrations of $\mathrm{NaBr}$ at $25^{\circ} \mathrm{C}$.

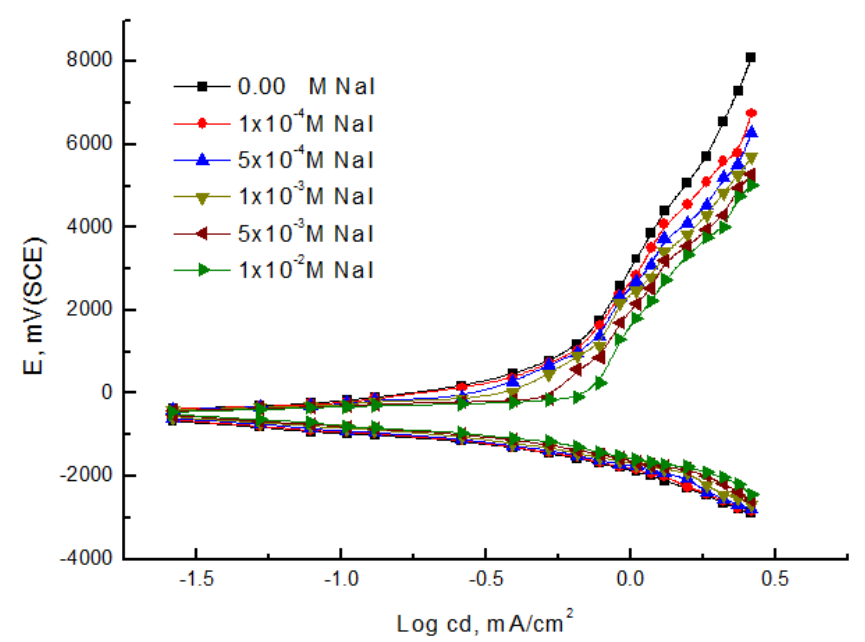

Fig. 8. Polarization curves of the indium electrode in $1 \times 10^{-3} \mathrm{M} \mathrm{Na}_{2} \mathrm{~B}_{4} \mathrm{O}_{7}$ solution devoid of-and containing different concentrations of $\mathrm{NaI}$ at $25^{\circ} \mathrm{C}$. 
Table 2. Variation of the kinetic parameters, $E_{c o r r}, i_{c o r r}, \beta_{a}, \beta_{c}$, and $R_{p}$ for indium electrode in $1 \times 10^{-3} \mathrm{M} \mathrm{Na} \mathrm{B}_{4} \mathrm{O}_{7}$ in absence and presence of increasing concentrations of $\mathrm{NaCl}, \mathrm{NaBr}$ and $\mathrm{NaI}$ as calculated from Figs. 6-8.

\begin{tabular}{|c|c|c|c|c|c|c|}
\hline Property & & $-\mathbf{E}_{\text {corr. }}, \mathbf{m V}$ & $\mathbf{i}_{\text {corr. }}, \mathrm{mAcm}^{-2}$ & $\beta_{\mathrm{a}}, \mathbf{m V}$ decade $^{-1}$ & $\beta_{\mathrm{c}}, \mathbf{m V}$ decade $^{-1}$ & $\mathbf{R}_{\mathbf{p}}, \mathbf{\Omega}$ \\
\hline \multirow{6}{*}{$\mathrm{NaCl}$} & $0.00 \mathrm{M}$ & 418 & 0.0354 & 558.37 & -493.36 & 2.43 \\
\hline & $1 \times 10^{-4} \mathrm{M}$ & 440 & 0.0524 & 659.07 & -468.02 & 0.002267 \\
\hline & $5 \times 10^{-4} \mathrm{M}$ & 452 & 0.0555 & 336.01 & -494.89 & 0.001564 \\
\hline & $1 \times 10^{-3} \mathrm{M}$ & 463 & 0.0575 & 288.20 & -455.81 & 0.001331 \\
\hline & $5 \times 10^{-3} \mathrm{M}$ & 475 & 0.0602 & 203.64 & -428.92 & 0.000993 \\
\hline & $1 \times 10^{-2} \mathrm{M}$ & 488 & 0.0630 & 176.84 & -446.14 & 0.000869 \\
\hline \multirow{5}{*}{$\mathrm{NaBr}$} & $1 \times 10^{-4} \mathrm{M}$ & 432 & 0.0489 & 665.01 & -459.88 & 0.002411 \\
\hline & $5 \times 10^{-4} \mathrm{M}$ & 445 & 0.0512 & 344.10 & -494.41 & 0.001746 \\
\hline & $1 \times 10^{-3} \mathrm{M}$ & 454 & 0.0537 & 294.14 & -461.48 & 0.001451 \\
\hline & $5 \times 10^{-3} \mathrm{M}$ & 466 & 0.0568 & 212.76 & -436.26 & 0.001090 \\
\hline & $1 \times 10^{-2} \mathrm{M}$ & 475 & 0.0588 & 181.62 & -451.56 & 0.000954 \\
\hline \multirow{5}{*}{$\mathrm{NaI}$} & $1 \times 10^{-4} \mathrm{M}$ & 425 & 0.0462 & 665.86 & -460.73 & 0.002647 \\
\hline & $5 \times 10^{-4} \mathrm{M}$ & 437 & 0.0489 & 350.03 & -505.35 & 0.001835 \\
\hline & $1 \times 10^{-3} \mathrm{M}$ & 446 & 0.0506 & 301.78 & -468.57 & 0.001572 \\
\hline & $5 \times 10^{-3} \mathrm{M}$ & 458 & 0.0530 & 220.21 & -454.65 & 0.001214 \\
\hline & $1 \times 10^{-2} \mathrm{M}$ & 463 & 0.0555 & 190.67 & -457.50 & 0.001049 \\
\hline
\end{tabular}

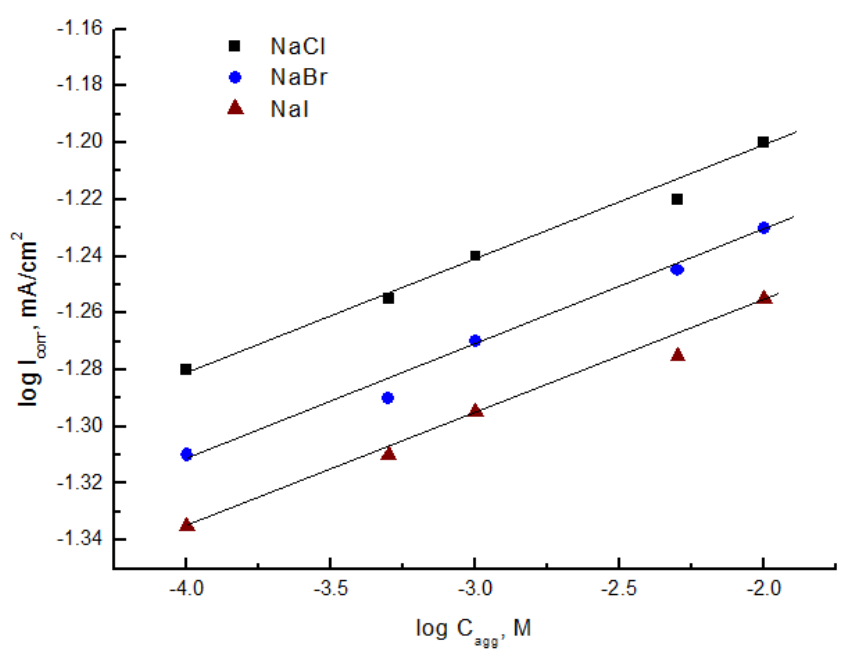

Fig. 9. Variation of the corrosion current density, $i_{\text {corr, }}$ of the indium electrode with the with the molar concentration of $\mathrm{NaCl}, \mathrm{NaBr}$ and $\mathrm{NaI}$ in $1 \times 10^{-3} \mathrm{MNa}_{2} \mathrm{~B}_{4} \mathrm{O}_{7}$ at $25^{\circ} \mathrm{C}$.

Further inspection of the data of Table (2) reveals that $\mathrm{R}_{\mathrm{p}}$ values are lower for $\mathrm{Cl}^{-}$than those reported for $\mathrm{Br}^{-}$and $\mathrm{I}^{-}$ ions. At the same time, the anodic slope, $\beta_{\mathrm{a}}$, determined in presence of $\mathrm{Cl}^{-}$ions is markedly lower than that determined in the case of $\mathrm{Br}^{-}$and $\mathrm{I}^{-}$ions. These observations reveal that $\mathrm{Cl}^{-}$ions are more aggressive than $\mathrm{Br}^{-}$and $\mathrm{I}^{-}$ions in the process of breakdown of the passive film on the indium surface [47]. The dependence of the corrosion current densities, $i_{\text {corr }}$, on the concentration of the aggressive $\mathrm{Cl}^{-}$, $\mathrm{Br}^{-}$and $\mathrm{I}^{-}$anions, is shown in Fig. 9. It is clear that with increasing the concentration of the aggressive anions, $\mathrm{i}_{\text {corr }}$ increases and varies with $\log \mathrm{C}_{\mathrm{agg}}$ according to:

$$
\log i_{\text {corr }}=a_{1}+b_{1} \log C_{a g g}
$$

where $a_{1}$ and $b_{1}$ are constants. From the curves of Fig. 9, one can concluded that with increasing the concentration of the aggressive anions, the corrosion current densities, $\mathrm{i}_{\text {corr }}$, increase. Approximately, parallel straight lines are obtained; this established that the mechanism of oxide film dissolution caused by these anions is the same.

\section{Conclusions}

The different factors affecting the oxide film formation and growth on indium electrode in sodium borate solutions by using polarization measurements were studied. Such factors were $\mathrm{Na}_{2} \mathrm{~B}_{4} \mathrm{O}_{7}$ concentrations, $\mathrm{pH}$, temperature and addition of $\mathrm{NaCl}, \mathrm{NaBr}$ and $\mathrm{NaI}$. The following conclusions could be drawn:

(1) The lower $\mathrm{Na}_{2} \mathrm{~B}_{4} \mathrm{O}_{7}$ concentrations, $\mathrm{pH}$ and decreasing of temperatures assist the oxide film formation on the surface of indium electrode.

(2) $\mathrm{E}_{\text {corr, }}$ shifts to more active values with increasing $\mathrm{Na}_{2} \mathrm{~B}_{4} \mathrm{O}_{7}$ concentration, $\mathrm{pH}$ and rising of solution temperature due to the partial dissolution of the oxide film.

(3) The corrosion current densities, $i_{\text {corr }}$, increase with increasing $\mathrm{Na}_{2} \mathrm{~B}_{4} \mathrm{O}_{7}$ concentration, $\mathrm{pH}$ and rising of solution temperature.

(4) The free activation energy of oxide film formation is calculated and found to be $15.708 \mathrm{kJmol}^{-1}$, indicating that the process of oxide film growth is under diffusion control.

(5) Addition of increasing concentrations of $\mathrm{NaCl}$, $\mathrm{NaBr}$ and $\mathrm{NaI}$ to the adjusted concentration of $\mathrm{Na}_{2} \mathrm{~B}_{4} \mathrm{O}_{7}$ increases the oxide film dissolution, which investigated from shifting of corrosion potentials, $\mathrm{E}_{\text {corr, }}$ to more active direction and increasing the values of corrosion current densities, $i_{\text {corr }}$.

\section{Acknowledgement}

The authors appreciate the financial support and facilities provided by the University of Zagazig to finish this work. 


\section{References}

[1] J. R. Mils, R. C. Bell and R. A. King, Rare Metals Handbook . 2nd Edn. Edited by C. A. Hampel. Chapman and Hall Ltd. London (1961) .p. 220.

[2] J.R. Mills, R.A. King, C.E.T. White, "Indium", C.A. Hampel (ed) Rare metals handbook, Chapman and Hall Ltd, London, 220-238 (1961).

[3] W. Koster and B. Thoma, Z. Metallkd., 46, 291 (1955).

[4] D.G. Avery, D.W. Goodwin, W.D. Lawson and T.S. Moss, Proc. Phys. Soc. B, 67, 761 (1954).

[5] S. Ozer and C. Besikci J. Phys D: Appl. Phys., 36, 559 (2003).

[6] C.S. Johnson, J.T. Vaughey, M.M. Thackeray, T. Sarakonsri, S.A. Hackney, L. Fransson, K. Edström and J.O. Thomas, Electrochem. Commun., 2, 595 (2000).

[7] M.I. Khan, X. Wang, K.N. Bozhilov and C.S. Ozkan, J. Nanomater., 2008, 698759 (2008).

[8] S.Y. Wang, S.H. Lin and Y.M. Houng, Appl. Phys. Lett., 51, 83 (1987); S. Wang, Fundamentals of semiconductor theory and device physics, Prentice-Hall, Englewood Cliffs, New Jersey, 523 (1989).

[9] T.S. Chao, C.L. Lee and T.F. Lei, J. Mater. Sci. Lett., 12, 721 (1993).

[10] T. Inushima, V.V. Mamutin, V.A. Vekshin, S.V. Ivanov, T. Sakon, M. Motokawa, S. Ohoya, J. Cryst. Growth, 227-228, 481 (2001).

[11] A.G. Bhuiyan, A. Hashimoto and A. Yamamoto, J. Appl. Phys., 94, 2779 (2003).

[12] T.P. Pearsall and M. Papuchon, Appl. Phys. Lett., 33, 640 (1978).

[13] W.J. Li, Y.N. Zhou and Z.W. Fu, Appl. Surf. Sci., 257, 2881 (2011).

[14] V.A. Williams, J. Electrochem. Soc., 113, 234 (1966).

[15] J.L. Vossen and E.S. Poliniak, Thin Solid Films, 13, 281 (1972).

[16] A. Yamamoto, M. Tsujino, M. Ohkubo and A. Hashimoto, Sol. Energ. Mat. Sol. C., 35, 53 (1994).

[17] H.P.T. Nguyen, Y.L. Chang, I. Shih and Z. Mi, IEEE J. Sel. Top. Quant., 17, 1062 (2011).

[18] H. Neff, O.K. Semchinova, A. M.N. Lima, A. Filimonov and G. Holzhueter, Sol. Energy Materials \& Solar Cells, 90, 982 (2006).

[19] S.W. Zeng, X.M. Cai and B.P. Zhang, IEEE J. Quantum Elect., 46, 783 (2010).

[20] S. Wagner and P.M. Bridenbaugh, J. Cryst. Growth, 39, 151 (1977).

[21] A.N. Tiwari, D.K. Pandya and K.L. Chopra, Sol. Energ. Mater., 15, 121 (1987).

[22] M. Kemell, M. Ritala and M. Leskelä, Crit. Rev. Solid State Mater. Sci., 30, 1 (2005).
[23] V. S. Saji, S. M. Lee and C. W. Lee, J. Kor. Electrochem. Soc., 14, 61 (2011).

[24] S.J. Duncan, G.T. Burstein, J. Appl. Electrochem. 17 (1987) 196.

[25] S. Omanovi'c, M. Metikoš-Hukovi'c, Solid State Ionics 78 (1995) 69.

[26] M. Metikoš-Hukovi'c, S. Omanovi'c, J. Electroanal. Chem. 455 (1998) 181.

[27] K. Wade, A.J. Banister, in: J.C. Bailar, H.J. Emeléus, Sir Ronald Nyholm, A.F. Trotman-Dickenson (Eds.), Comprehensive Inorganic Chemistry, vol. 1, Pergamon Press, Oxford, 1973.

[28] S.Omanovic and M. Metikos-Hukovic, Solid State Ionics 78 (1995) 69.

[29] M .Metikos-Hukovic and S. Omanovic, J. Electroanal. Chem. 455 (1998) 181-189.

[30] S.B. Saidman, E.C. Bellocq, J.B. Bessone, Electrochim. Acta 35 (1990) 329-338.

[31] S.Omanovic and M. Metikos-Hukovic, J. Appl. Electrochem., 27( 1997) 35-41.

[32] S.B. Saidman, J.B. Bessone, Electrochim. Acta, 36(1991) 2063-2067.

[33] A.G. Munoz, J.B. Bessone, Electrochim. Acta, 43 (1998) 2033-2040.

[34] S. Omanovic and M. Metikos-Hokovic, Thin Solid Films, 458, 52 (2004).

[35] M. Stern and A.L. Geary, J., Electrochem. Soc., 104(1957) 56.

[36] S.B. Saidman, E.C. Bellocq, J.B. Bessone, Electrochim. Acta 35 (1990) 329.

[37] S. Omaovic and M. Metikos-Hukovic., Solid State Ionics 78 (1995) 69-78.

[38] T. Popova, N.A. Simonova, Izv. Akad. Nauk. SSSR. Ser. Khim. 7 (1963) 1086.

[39] R. Piercy, N.A. Hampson, J. Electroanal. Chem. 53 (1974) 271.

[40] R.D. Armstrong, A.B. Suttie, H.R. Thirsk, Electrochim. Acta 13 (1968) 1.

[41] F. Faizullin, N.A. Amirkhanova, Elektrokhimiya 2 (1966) 80.

[42] A. G. Munoz and J. B. Bessone, J. Electrochimica Acta, 43, 14-15(1998) 2033-2040.

[43] J.M. Abd El Kader and A.M. Shams El Din, British Corrosion Journal 4(1979) 40-45.

[44] Yonghwa Chung and Chi-Woo Lee, Journal of Electrochemical Science and Technology, 3, No. 1, (2012) $1-13$

[45] A.M. Bond, J. Electrochem. Soc., 119, 1503 (1972).

[46] P. Kondziela and J. Biernat, J. Electroanal. Chem., 61, 281 (1975). 
[47] C. Nanjundiah and R. Narayan, Electrochim. Acta, 26, 203 (1981). 